\title{
EFL Learners' Willingness to Communicate, Language Learning Orientation, and Social Support in Kampung Inggris Pare
}

\author{
Saidah \\ Institute Agama Islam Negeri Kediri, Indonesia \\ Email: idasaidah@iainkediri.ac.id
}

Submitted: $\mathbf{1 1 / 1 1 / 2 0 2 0}$

Revised: 30/12/2020

Accepted: 17/01/2021

E-ISSN : $2579-4574$

P-ISSN : $2549-7359$

\begin{abstract}
: this current study conducted to investigate any significant relationship among students' willingness to communicate and language learning orientation as well as any significant relationship between students' WTC and social support. It used quantitative design. There were 78 students participated in this study. They were studying English in Kampung Inggris Pare. For collecting the data, the students were asked to fill out three questionnaires; WTC questionnaire consist of 25 items, Language learning orientation questionnaire of20 items, and social support of 6 items. Pearson Product moment correlation was applied for calculating the data to know any possible correlation between the variables. From the data analysis showed that any significant correlation between students' willingness to communicate and their language learning orientation. However, there was no any significant correlation between students' WTC and social support. The result of the study showed that students' language learning orientation is the best motivation for students to improve their English proficiency trough their willingness to communicate in regard to four English skills, speaking, reading, writing and comprehension. Although social support over all did not give significant correlation, some support from other friend and teacher positively correlated to students' WTC in regard to speaking and writing skill.
\end{abstract}

Keywords: Willingness to Communicate, Language Learning Orientation, Social Support

https://ojs.unm.ac.id/eralingua

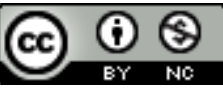

This work is licensed under a Creative Commons Attribution-NonCommercial 4.0 International License 


\section{INTRODUCTION}

The teaching of English language recently emphasized on students' communicative competence and the language use for communication (Cetinkaya, 2005). Students' meaningful communication is the main goal of second language acquisition process (Khajavy et al., 2016) added "recent trends of second language pedagogy, if someone wants to develop his/her English proficient, they must use the language and learn to talk. The students cannot be fluent unless they have more practice speaking in English. However, some students speak up, while others are still hesitated to speak the second language. This situation is caused by some factors.

The idea of willingness to communicate (WTC) was invented by McCroskey and Baer (McCroskey \& Baer, 1985). it is defined as students' willingness to participate into communication in speech or writing at a special time with a particular person or the persons who uses a second language in their communication persons (Maclntyre, Clément, et al., 1998). WTC is crucial on students' second language acquisition (Nadafian \& Mehrdad, 2015). It shows that no matter how smart someone is in using a foreign language if he does not want to use it he will not be able to communicate well (Howatt 1984, as cited in (Mohammadzadeh \& Jafarigohar, 2012). Many studies have been conducted to investigate some factors that related to L2 WTC. It was found that The L2 willingness to communicate has correlation to students' motivation (Hashimoto, 2002), integrative motivation (Peng, 2007), (Alqahtani, 2015) gender (Nadafian \& Mehrdad, 2015), multiple intelligence (Mohammadzadeh \& Jafarigohar, 2012). motivation, social and culture are several factors that affects students' willingness to communicate in English which effect students' success in learning English (Alqahtani, 2015). language learning orientation (Zarrinabadi \& Abdi, 2011) and social support (Maclntyre et al., 2001) also had correlation to the L2 WTC.

Most studied about L2 WTC conducted western countries. This topic has not been conducted many researchers in Indonesian context, therefore, the recent study focuses on the relation among EFL learners' willingness to communicate, language learning orientation, and social support in Indonesian context. This study conducted in a small village called Kampung Inggris. It is located in Pare, Kediri Indonesia. It is very special place, as there are hundreds English courses in this village. Now days "Kampung Inggris" becomes an educational tour for Indonesian students who want to improve their English proficiency. Most students comes to pare in school holiday moment, they spend their holiday time while studying English in this place. The students who come to Kampung Inggris considered English as their second language. They are staying in English dormitory which obligates them to speak English for 24 hours. They are encouraged to speak English inside or outside the classroom. Even when they come to food stall they are able to practice their speaking, since some sellers have good English proficient. This condition also is believed supports the students to have willingness to learn and communicate in English without hesitation. Therefore, this recent study has three objectives: (1) To measure the relationship between EFL students' willingness to communicate and their language learning orientation, (2) To measure the relationship between EFL 
students' willingness to communicate and their language learning orientation, and (3) To measure the relationship between EFL students' willingness to communicate and social support.

\section{REVIEW OF RELATED LITERATURE}

\section{Willingness to communicate}

The term of Willingness to communicate (WTC) proposed by McCroskey and Baer (McCroskey \& Baer, 1985) was firstly introduced in the first language (L1) communication context and acquisition. In L1 context, WTC considered as a personality trait which showed that a person has the same WTC tendencies in every situations (Maclntyre, Dörnyei, et al., 1998). However, WTC in the context of second language learning is different in first language context.

Maclntyre et al. (1998) recognizes that individual differences that interact in more complex communications manner cause the difference WTC in L1 and L2 context. L2WTC defined students' willingness to participate into communication in speech or writing at a special time with a particular person or persons who uses a second language in their communication persons (Maclntyre, Clément, et al., 1998). Some factors affected L2 WTC in classroom context are learning style, identity style, age, gender, and teacher communication behavior.

\section{Language learning orientations}

Gardner \& lambert divided students' learning orientations into two categories: instrumental and integrative orientation (Gardner \& Lambert, 1959) . Instrumental orientation is a learning a L2 pragmatic goals, while, Integrative orientation means an intention to become a member $\mathrm{L} 2$ group and to do interaction with this group. Learning language for finding a job and increasing salary include in instrumental orientations (Gardner \& Lambert, 1959).

Zhou (Zhou, 2016) introduced a corporative learning orientation which supports an effective learning situation to promote L2 not only in learners' linguistic development but also in students' cognitive development (Kagan, 1995). Through corporative learning, the students have more opportunities to do meaningful interaction with their teacher and peers while they share their ideas (Ghaith, 2003). Motivation and orientation in learning second language are related to each other. Gardner and Lambert (1959) suggested both orientation and attitude are affected students' motivation for learning second language.

\section{Social support}

Social support gives a lot of contribution in language learning to improve students' WTC in L2 context (Maclntyre et al., 2001). It might influence students behavioral attentions on L2 WTC (Fishbein \& Ajzen, 1980). This support can be from several sources, Including parents, teachers, and peers, so that they have opportunity to do communication. Obviously, support from teacher and friends give students chance to have meaningful communication inside and outside the classroom. Support from parents can be encouragement for students to have real communication at home. Without these support students' opportunity to have authentic communication and their WTC is likely low. 
In the past decade, MacIntyre et al. (2001) conducted a research to investigate the correlation language orientation and social support to immersion students' willingness to communicate which revealed that support from friend gave higher contribution to students' WTC when they are outside the class. But it give less contribution when they communicate in English inside the classroom (Maclntyre et al., 2001). Further, the recent study which found that students' learning orientations are correlated to L2 WTC of students when they are in the class and when they are not in class (Zarrinabadi \& Abdi, 2011). The finding told that language learning orientations has less correlation to students' WTC inside the classroom.

Nadafian \& Mehrdad (Nadafian \& Mehrdad, 2015) measured the relation of gender to students' WTC which showed that male and female students have no significant difference in their willing in learning and using English in their communication. However, motivation, social and culture are factors which are crucial to students' willingness to learn and to use English in their communications with friends, teachers and societies. It can be influence the students success in learning foreign and second language (Alqahtani, 2015). The study which focuses on the relationship WTC and some factors correlated to it needs to be conducted more particularly in Indonesian context. To fill this gap, this study conducted to measure the correlation among students' willingness to communicate outside the classroom, students' orientations in learning English and social support from friends, teachers, family and societies.

\section{RESEARCH METHOD}

\section{Research Design}

Quantitative design was used in this study which the research data can be statically computed. This research conducted was to measure the relationship between EFL students' willingness to communicate outside the classroom and each component of their language orientations, and to measure the relationship between EFL students' willingness to communicate outside the classroom and social support.

\section{Participants}

The students who participate in this study were the students who were studying English in Kampung Inggris Pare. There were 78 students participated in this study. They were the students of ELFAST English Course who took TOEFL Program. These classes were chosen because they took TOEFL Program for various reasons for different orientations. This study was conducted in February 2020 before Corona pandemic in Indonesia. All courses in Kampung Inggris Pare are off now because of the Corona Pandemic. In Pare, the students are encouraged to practice their speaking whether in the class or outside the class. This recent study aimed to measure the relation among students' willingness to communicate outside class, students' language orientations studying English in Kampung Inggris, and the social support from friends, family and societies around the English courses. 


\section{Instruments}

Willingness to communicate

Students' WTC outside the classroom is measured by questionnaire created by MacIntyre et al. (Maclntyre et al., 2001). This questionnaire is modified before it is administrated to the participants. It contains 27 items in a likert-type scale. To ensure that the instruments are valid, the researcher tested using Pearson Product Moment. Cronbachs' Alpha was used to measure the reliability of instruments. Then, the result of $R$ obtained compared with $r$ value $(r 78=.22)$. From the comparison, all items had $r$ obtained higher than $r$ value. So, the researcher could conclude that the items of questionnaire were valid. The reliability statistics showed .921. It could be concluded that the questionnaire is reliable.

Orientations for language learning

Students 'orientations studying English in Kampong Inggris are measured by questionnaire in a likert-type scale. It is adapted from Maclntyre et al. (Maclntyre et al., 2001). In this questionnaire students' orientations in learning English in Pare are divided into scholarship, language achievement, school holiday, job-related, knowledge, and friendship presented in the scale. Then, the result of $\mathrm{R}$ obtained compared with $r$ value $(r 78=.22)$. From the comparison, all items had $r$ obtained higher than $r$ value. So, the researcher could conclude that the items of questionnaire were valid. The reliability statistics showed .965 which could be concluded that the questionnaire is reliable.

Social support

Six questions adapted from Ajzen's (Ajzen, 2005) are prepared to measure students' social support. It was also used by Maclntyre et al. (Maclntyre et al., 2001) to measure students 'support from friends, family, and societies around BEC English course. The students' answers "yes" or "no" questions to know who supports and encourages them in using English for communication. From the comparison, all items had $r$ obtained higher than $r$ value. It shows that all items of questionnaire were valid. The reliability statistics showed .786 which could be concluded that the questionnaire is reliable.

\section{Data Analysis}

The researcher uses SPSS 15.0 to analyze the data from the questionnaires. The researcher uses a product moment correlation to know the relationship between students' WTC outside the class and students' orientations in learning English. It is also to know the relationship between students' WTC outside the class and social support they get from friends, teachers, family and societies. 


\section{FINDING AND DISSCUSSION}

\section{Descriptive Statistic}

\section{Students' Willingness to Communicate}

Students' willingness to communicate score is the result of students' willingness to communicate levels which were obtained from the questionnaire. Here is the descriptive statistics result of the students' willingness to communicate score.

Table 1. The Descriptive Statistic of Students' Willingness to Communicate Score

\begin{tabular}{|c|c|c|}
\hline \multicolumn{3}{|c|}{ willingness to communicate } \\
\hline \multirow{2}{*}{$\mathrm{N}$} & Valid & 78 \\
\hline & Missing & 0 \\
\hline \multicolumn{2}{|c|}{ Mean } & 79.05 \\
\hline \multicolumn{2}{|c|}{ Median } & 35.00 \\
\hline \multicolumn{2}{|c|}{ Std. Deviation } & 17.381 \\
\hline \multicolumn{2}{|c|}{ Variance } & 302.101 \\
\hline \multicolumn{2}{|c|}{ Range } & 73 \\
\hline \multicolumn{2}{|c|}{ Minimum } & 45 \\
\hline \multicolumn{2}{|c|}{ Maximum } & 118 \\
\hline \multicolumn{2}{|c|}{ Sum } & 6166 \\
\hline
\end{tabular}

Based on data above (table 1), there can be found that the mean of students' willingness to communicate score from 78 students is higher than the score of the standard deviation. It can be concluded that the spread of data is good enough.

\section{Students' Orientation}

Students' orientation is objective of studying English in "Kampung Inggris" Pare. It is believed that it has given a big influence on their willingness to communicate. Studying foreign language needs a lot of practice to improve their skills. Communicating with others in English is the way they keep practicing this language. Here is the descriptive statistic of students' orientation score.

Table 2. The Descriptive Statistic of Students' Orientation Score

\begin{tabular}{|c|c|c|}
\hline \multicolumn{3}{|c|}{ Students Orientation } \\
\hline \multirow{2}{*}{$\mathrm{N}$} & Valid & 78 \\
\hline & Missing & 0 \\
\hline \multicolumn{2}{|c|}{ Mean } & 96.81 \\
\hline \multicolumn{2}{|c|}{ Std. Deviation } & 18.579 \\
\hline \multicolumn{2}{|c|}{ Variance } & 345.196 \\
\hline \multicolumn{2}{|c|}{ Range } & 96 \\
\hline \multicolumn{2}{|c|}{ Minimum } & 24 \\
\hline \multicolumn{2}{|c|}{ Maximum } & 120 \\
\hline \multicolumn{2}{|c|}{ Sum } & 7551 \\
\hline
\end{tabular}


Based on the table above (table 2), it can be seen that the mean of the students' orientation score is 96.81 with standard deviation score is 18.579. It indicates that the spread of the data is good enough because the mean score is higher than standard deviation score.

\section{Social Support}

Social support is also measured in this study. Thee social support score is obtained from the questionnaire give to the students to know their family, teacher and friend support on their English study. Here is the descriptive statistic of the social support.

Table 3.The Statistic of Social Support Score

\begin{tabular}{|c|c|c|}
\hline & & tion \\
\hline & Valid & 78 \\
\hline $\mathrm{N}$ & Missing & 0 \\
\hline & & 4.12 \\
\hline & eviation & 1.947 \\
\hline & & 3.792 \\
\hline & & 6 \\
\hline & um & 0 \\
\hline & num & 6 \\
\hline $\mathrm{Su}$ & & 321 \\
\hline
\end{tabular}

Based on the data above (table 3), it can be illustrated that the mean score of the communication strategies used by the students is 4.12. For the standard deviation value of the social support for the students is 1.947 which is lower than the mean. This means that the data spread is good.

\section{Statistical Analysis}

\section{Normality Test}

To compute and analyze the normality of the data collected, the researcher utilizes One-Sample Kolmogorov-Smimov test using SPSS 15.0 statistic computational program. Data is spread normally if the significance (sig.) number of data obtained is greater than 0.05 ( $p>.05)$, but if it is lower than or equal to 0.05 ( $p$ $\leq .05)$, it can be concluded that the data distribution is abnormal 
Table 4. Normality Test of All Variables

\begin{tabular}{ccc}
\hline & $\mathrm{N}$ & 78 \\
\hline \multirow{2}{*}{ Normal Parameters(a,b) } & Mean & .0000000 \\
& Std. Deviation & 15.05185497 \\
\hline Most Extreme & Absolute & .051 \\
Differences & Positive & .048 \\
& Negative & -.051 \\
\hline Kolmogorov-Smirnov Z & .448 \\
\hline Asymp. Sig. (2-tailed) & .988
\end{tabular}

According to the table above (table 4), the significant value (sig.) is higher than .05. It can be seen from most extreme difference score is .051. It is higher than .05. It can be inferred that the data distribution is normal. Due to that normal distribution, the researcher uses Pearson Product Moment to find the correlation between EFL students' willingness to communicate and their orientation in studying English and the social support.

\section{The Correlation between EFL Students' Willingness to Communicate and Students' Orientation}

Here is the result of the correlation between EFL students' willingness to communicate and students' Orientation

Table 5. Table of Correlation between EFL Students' Willingness to Communicate and Students' Orientation

\begin{tabular}{llrr}
\hline & & WTC & \multicolumn{1}{c}{ Orientation } \\
\hline WTC & $\begin{array}{l}\text { Pearson } \\
\text { Correlation }\end{array}$ & 1 & $.492(* *)$ \\
\hline & Sig. (2-tailed) & & .000 \\
\hline & $\mathrm{N}$ & 78 & 78 \\
\hline $\begin{array}{l}\text { Orientati } \\
\text { on }\end{array}$ & Pearson & $.492(* *)$ & 1 \\
\hline \multicolumn{4}{c}{ Correlation } \\
\hline & Sig. (2-tailed) & .000 & 78 \\
\hline & $\mathrm{N}$ & 78 & \\
\hline
\end{tabular}

The table above is pointed out the result of the correlation between EFL students' willingness to communicate and students' orientation which shows that there is a significant correlation between both variables. According to the data above, the value of Sig. is lower than 0.05 (sig. value $=0.00 \leq 0.05$ ). As a result, the null hypothesis is rejected. From the table above, the correlation coefficient of both variables is $0.492(r=0.492)$. According to correlation coefficient index, the correlation of both variables is strong enough.

Next, testing the correlation among students' orientation with students' willingness to communicate (WTC) in four skills, speaking, reading, writing and comprehension. Here is the result of the correlation. 
Table 6. Correlations between Students Orientation and Willingness to Communicate

\begin{tabular}{|c|c|c|c|c|c|c|}
\hline & & Job & Travel & Friendship & $\begin{array}{l}\text { Personal_kno } \\
\text { wledge }\end{array}$ & $\begin{array}{c}\text { School_achi } \\
\text { evement }\end{array}$ \\
\hline \multirow[t]{3}{*}{ WTC_Speaking } & $\begin{array}{l}\text { Pearson } \\
\text { Correlation }\end{array}$ & $.261\left(^{*}\right)$ & $.329(* *)$ & $.371(* *)$ & $.282(*)$ & $.318(* *)$ \\
\hline & Sig. (2-tailed) & .021 & .003 & .001 & .012 & .005 \\
\hline & $\mathrm{N}$ & 78 & 78 & 78 & 78 & 78 \\
\hline \multirow[t]{3}{*}{ WTC_Reading } & $\begin{array}{l}\text { Pearson } \\
\text { Correlation }\end{array}$ & $.354(* *)$ & $.402(* *)$ & $.376(* *)$ & $.367(* *)$ & $.330(* *)$ \\
\hline & Sig. (2-tailed) & .001 & .000 & .001 & .001 & .003 \\
\hline & $\mathrm{N}$ & 78 & 78 & 78 & 78 & 78 \\
\hline \multirow[t]{3}{*}{ WTC_Writing } & $\begin{array}{l}\text { Pearson } \\
\text { Correlation }\end{array}$ & $.328(* *)$ & $.409(* *)$ & $.441(* *)$ & $.403(* *)$ & $.374(* *)$ \\
\hline & Sig. (2-tailed) & .003 & .000 & .000 & .000 & .001 \\
\hline & $\mathrm{N}$ & 78 & 78 & 78 & 78 & 78 \\
\hline \multirow[t]{3}{*}{$\begin{array}{l}\text { WTC_comprehe } \\
\text { nsion }\end{array}$} & $\begin{array}{l}\text { Pearson } \\
\text { Correlation }\end{array}$ & $.408(* *)$ & $.486(* *)$ & $.471(* *)$ & $.458(* *)$ & $.444(* *)$ \\
\hline & Sig. (2-tailed) & .000 & .000 & .000 & .000 & .000 \\
\hline & $\mathrm{N}$ & 78 & 78 & 78 & 78 & 78 \\
\hline
\end{tabular}

As the table above shows, the value of significance for the correlation of students' willingness to communicate with the students' orientation are lower than .05. Therefore, it can be sum up that there is a significant correlation between students' WTC and students' learning; The result of this present study revealed that there is a significant correlation between EFL students' willingness and students 'orientation. Willingness to communicate (WTC) was measured in 4 skill areas: speaking, reading, writing and comprehension. While, there were 5 orientations or reasons of studying English in pare examined in this study: job, travel, friendship, personal knowledge, and school achievement.

Job, travel, friendship, knowledge and school achievement are strongly correlated to students' WTC in regard to comprehension skill. It indicates the strongest correlation among other skills. Their correlation scores are above 0.400 . Student's reason of studying English for travel gives big influence on students' willingness to communicate in comprehension skill. Zarrinabadi and Abdi also said that Job, travel, and Friendship are correlated with four language skills, listening, speaking writing and reading (Zarrinabadi \& Abdi, 2011). Travel, friendship and personal knowledge also have strongly correlated to students' WTC in writing skill. Students' orientation gave strong influence on students WTC in writing skill areas. This data could be seen that writing a letter and doing chatting with friend are preferable. The students prefer to Communicating with people in writing is limitless nowadays with support from the technology of smart phones. Social media such as Facebook, Instagram, and WhatsApp is the most chosen platform of communication by millennial generations. 
Travel-related orientation had strongly correlated to students; WTC in reading skills. It showed that the students are encouraged to read something in English such book, article, newspapers and movie review. By reading some English resources, they will get basic knowledge for traveling in English speaking country someday. Friendship has significantly correlated to students WTC in regard to speaking skill. Besides, school achievement is strong enough correlated to students' WTC in speaking skill. Most of students who are studying in Kampung Inggris come from different places with a variety of cultural background. They stay in Pare only few months. They prefer to spend school holiday by improving their English proficiency. Living in new place make them meet new people. Therefore, it is the best motivation to make new friends as well while improving their English skills and spending their school holiday.

\section{The Correlation between EFL Students' Willingness To Communicate And Social Support}

Here is the result of the correlation between EFL students' willingness to communicate and social support.

Table 7. Table of Correlation between EFL Students' Willingness to Communicate and Social Support

\begin{tabular}{llrr}
\hline & & WTC & \multicolumn{1}{c}{ Social } \\
\hline WTC & Pearson Correlation & 1 & .095 \\
\hline & Sig. (2-tailed) & & .408 \\
\hline $\mathrm{N}$ & 78 & 78 \\
\hline Social & Pearson Correlation & .095 & 1 \\
\hline & Sig. (2-tailed) & .408 & \\
\hline $\mathrm{N}$ & 78 & 78 \\
\hline
\end{tabular}

The table above is pointed out the result of the correlation between EFL students' willingness to communicate and social support which shows that there is no a significant correlation between both variables. According to the data above, the value of Sig. is higher than 0.05 ( $\mathrm{sig}$. value $=0.408>0.05$ ). From the table above, the correlation coefficient of both variables is $0.095(r=0.095)$. According to correlation coefficient index, the correlation of both variables is very weak.

Next, testing the correlation among social support with students' willingness to communicate (WTC) in four skills, speaking, reading, writing and comprehension. Here is the result of the correlation. 
Table 8. Correlations between Students Orientation and Willingness to Communicate

\begin{tabular}{|c|c|c|c|c|c|c|}
\hline & & Parents & $\begin{array}{c}\text { Sister_Brot } \\
\text { her }\end{array}$ & Best_friend & Other_frien $_{\mathrm{d}}$ & Teacher \\
\hline \multirow[t]{3}{*}{ WTC_Speaking } & $\begin{array}{c}\text { Pearson } \\
\text { Correlation }\end{array}$ & .049 & .088 & .111 & $.296(* *)$ & $.235\left(^{*}\right)$ \\
\hline & Sig. (2-tailed) & .669 & .444 & .332 & .009 & .039 \\
\hline & $\mathrm{N}$ & 78 & 78 & 78 & 78 & 78 \\
\hline \multirow[t]{3}{*}{ WTC_Reading } & $\begin{array}{c}\text { Pearson } \\
\text { Correlation }\end{array}$ & -.003 & -.076 & -.139 & .015 & -.106 \\
\hline & Sig. (2-tailed) & .982 & .510 & .224 & .896 & .354 \\
\hline & $\mathrm{N}$ & 78 & 78 & 78 & 78 & 78 \\
\hline \multirow[t]{3}{*}{ WTC_Writing } & $\begin{array}{c}\text { Pearson } \\
\text { Correlation }\end{array}$ & -.034 & .087 & .046 & $\left..255^{*}\right)$ & -.057 \\
\hline & Sig. (2-tailed) & .770 & .450 & .692 & .024 & .622 \\
\hline & $\mathrm{N}$ & 78 & 78 & 78 & 78 & 78 \\
\hline \multirow[t]{3}{*}{$\begin{array}{l}\text { WTC_Comprehen } \\
\text { sion }\end{array}$} & $\begin{array}{c}\text { Pearson } \\
\text { Correlation }\end{array}$ & -.011 & -.033 & -.007 & .097 & -.019 \\
\hline & Sig. (2-tailed) & .926 & .773 & .953 & .397 & .870 \\
\hline & $\mathrm{N}$ & 78 & 78 & 78 & 78 & 78 \\
\hline
\end{tabular}

As the table above shows, the correlation score of students' willingness to communicate with the social support is higher than .05. Therefore, it can be sum up that it didn't have significant correlation between social support and students' WTC. The score of social support and students' willingness to communicate in speaking skills indicates significantly correlation. Support from other friend and teacher are significantly correlated to students' WTC in speaking skill. Support from other friend also gives positive correlation to students writing skills. Studying English in Pare make them separate with family and friend. Support from Family and siblings were not correlated significantly (Kalsoom et al., 2020). This condition make them only get support from teacher and other friends, the people who could meet the most while they are living in Kampung Inggris.

\section{CONCLUSION}

The result showed that there is a significantly correlation between students orientation and students willingness to communicate. This data supported the fact that many students come to Pare for studying English with good motivation and orientation. They study English for continuing their study and getting scholarship. However, from the result of the study, it did not find that social support has correlation with students 'willingness to communicate when they studying English in Pare. 


\section{REFERENCES}

Ajzen, I. (2005). Attitudes, personality, and behavior. McGraw-Hill Education (UK).

Alqahtani, M. (2015). Saudi Students' Willingness to Communicate and Success in Learning English as a Foreign Language. Journal of Language Teaching and Research, 6(6), 1195-1205. DOI: http://dx.doi.org/10.17507/jltr.0606.06

Cetinkaya, Y. B. (2005). Turkish college students' willingness to communicate in English as a foreign language [PhD Thesis]. The Ohio State University.

Fishbein, M., \& Ajzen, I. (1980). Predicting and understanding consumer behavior: Attitude-behavior correspondence. Understanding Attitudes and Predicting Social Behavior, 148-172.

Gardner, R. C., \& Lambert, W. E. (1959). Motivational variables in second-language acquisition. Canadian Journal of Psychology/Revue Canadienne de Psychologie, 13(4), 266.

Ghaith, G. (2003). Effects of the learning together model of cooperative learning on English as a foreign language reading achievement, academic self-esteem, and feelings of school alienation. Bilingual Research Journal, 27(3), 451-474. http://dx.doi.org/10.1080/15235882.2003.10162603

Hashimoto, Y. (2002). Motivation and willingness to communicate as predictors of reported L2 use: The Japanese ESL context. Second Language Studies, 20(2), 29-70.

Kagan, S. (1995). We Can Talk: Cooperative Learning in the Elementary ESL Classroom. ERIC Digest.

Kalsoom, A., Soomro, N. H., \& Pathan, Z. H. (2020). How Social Support and Foreign Language Anxiety Impact Willingness to Communicate in English in an EFL Classroom. International Journal of English Linguistics, 10(2). DOI: 10.5539/ijel.v10n2p80

Khajavy, G. H., Ghonsooly, B., Hosseini Fatemi, A., \& Choi, C. W. (2016). Willingness to communicate in English: A microsystem model in the Iranian EFL classroom context. Tesol Quarterly, 50(1), 154-180. https://doi.org/10.1002/tesq.204

Maclntyre, P. D., Baker, S. C., Clément, R., \& Conrod, S. (2001). Willingness to communicate, social support, and language-learning orientations of immersion students. Studies in Second Language Acquisition, 23(3), 369388.

Maclntyre, P. D., Clément, R., Dörnyei, Z., \& Noels, K. A. (1998). Conceptualizing willingness to communicate in a L2: A situational model of L2 confidence and affiliation. The Modern Language Journal, 82(4), 545-562. DOI: $10.1017 /$ S0272263101003035

McCroskey, J. C., \& Baer, J. E. (1985). Willingness to communicate: The construct and its measurement.

Mohammadzadeh, A., \& Jafarigohar, M. (2012). The Relationship between Willingness to Communicate and Multiple Intelligences among Learners of English as a Foreign Language. English Language Teaching, 5(7), 25-32. DOl:10.5539/elt.v5n7p25 
Nadafian, M., \& Mehrdad, A. G. (2015). The Relationship between EFL Students" Gender and their Willingness to Communicate in Same-Sex Classrooms. International Journal of Educational Investigations, 2(1), 93-102.

Peng, J. E. (2007). Willingness to communicate in an L2 and integrative motivation among college students in an intensive English language program in China. University of Sydney Papers in TESOL, 2(1), 33-59.

Zarrinabadi, N., \& Abdi, R. (2011). Willingness to Communicate and Language Learning Orientations in Iranian EFL Context. International Education Studies, 4(4), 206-214. doi:10.5539/ies.v4n4p206

Zhou, M. (2016). The roles of social anxiety, autonomy, and learning orientation in second language learning: A structural equation modeling analysis. System, 63, 89-100. DOI: 10.1016/j.system.2016.09.001 